\title{
Celestina - a Spanish Novel on the East German Stage before and after German Reunification
}

\author{
Gabriele Eckart \\ Southeast Missouri State University
}

Fernando de Rojas' novel in dialogue Celestina (1499) tells the story of the unfortunate lover Calisto who employs the services of the old crone Celestina in order to enjoy the favors of the beautiful Melibea. This famous Spanish story about love, sex, greed and intrigue has been adapted for the stage many times during the last five hundred years, all over Europe. In the following, I will compare two adaptations by East German authors, one written before and one after the fall of the Berlin Wall in 1989. Both adaptations, while clearly connected to Fernando de Rojas' text, change the story line in different ways that reflect the very different contexts in which they were written. While Mickel's adaptation of Celestina (1974) includes scenes about the Inquisition and concrete allusions to life in the GDR to hint at the fact that people were constantly under surveillance by the state police, Wekwerth's adaptation (2002) clearly criticizes the changes that capitalism brought about in this part of the world after the collapse of the GDR. While most East Germans had greeted the German reunification enthusiastically, Wekwerth stated skeptically about this event: "Se habla de 'democratización' cuando se asalta a un país y se restaura el capitalismo» ("Teatro de Brecht. ¿Una respuesta a nuestra tiempo?» 4) In order to reach his goal of political criticism, Wekwerth in his adaptation refers to plays by Bertolt Brecht and uses strategies of his epic theater.

Fernando de Rojas' text, at first glance, seems to be a warning about procuresses and corrupt servants. Calisto, a rich young man who is in love with Melibea but cannot reach her, commits the error of trusting them. He must pay for this error with his life. Melibea, in desperation 
about his death, jumps from a tower and dies also. During the seventeenth century, Celestina was censored in Spain; between 1633 and 1821 there was not one new edition (see Briesemeister 102). Very likely, the text caused offense due to the fact that Calisto in his infatuation raises Melibea to the position of God: «Sempronio: ¿Tú no eres cristiano? Calisto: ¿Yo? Melibeo só, y a Melibea adoro, y en Melibea creo, y a Melibea amo» (Rojas 22). This heresy in the eyes of the Church and the figure of Calisto from whose fresh mouth it came seem to be the main reason for the GDR writer Karl Mickel's strong interest in de Rojas' tragicomedy. It permits him to insert two other protagonists into the text: an Inquisitor and his secretary, whose job it is to deal with cases of heresy. In the end of the play, it turns out that all intrigues in the text have not just been observed by these two protagonists, but planned. The death of Calisto, Melibea, and the others, according to Mickel, is the result of the work of the Inquisition. Due to this Orwell-like dimension, critics called Mickel's play "a parody on the perfect state» (Zingg). It goes without saying that because of this dimension, the author had problems with the East German censorship office that saw in Mickel's depiction of the Inquisition a criticism of the feared GDR State Police. Although performed on stage in Berlin in 1974 - in a short time period of more political tolerance after the dismissal of party boss Walter Ulbricht - the text could not be published until 1980. East German critics and scholars clearly ignored it until 1985.

As Christoph Rodiek shows, the motif of the Inquisition is nothing new in German adaptations of Fernando de Rojas' text. However, in West German adaptations, this motif only served as a decorative touch to give the work local color, showing the Inquisition as being something specifically Spanish. By contrast, in Mickel's text, this motif becomes a «differenziert gestaltetes Mittel literarischer Erkenntnis» / ("a distinctly formed means of literary realization") (160). Mickel's two scenes in which the Inquisitor and his secretary observe what is going on take place in front of the curtain. In contrast to all other scenes of the play in verse, these scenes are written in prose to highlight the action's bureaucratic nature. During the first scene, the secretary informs his supervisor about Calisto's heretical statement raising Melibea to the position of God as well as about a serious error committed by Sempronio, Calisto's servant. He was aware of his master's heresy, but did not denounce it to the police. The audience knows that nobody else had been present during Calisto's and Sempronio's conversation about Melibea; consequently, Calisto's house must have been bugged. With this change, the text becomes relevant to the situation in the GDR with the omnipresence of the state police in people's lives, when political conversations were avoided inside houses for fear of hidden microphones. Afterwards, the secretary asks the Inquisitor what steps he should take against Calisto and his servant. Surprisingly, the answer is: «Keine!» / («None!») (164) It turns out the Inquisitor knew that all 
persons had so strongly internalized the Inquisition that - without being aware of it - they behaved as if they were programmed according to its rules. Therefore, it was not necessary to take any steps. A good example of this internalization is Sempronio's remark to Parmeno that they could play the "Inquisitionsspiel» / ("game of Inquisition») with Celestina if she doesn't want to share the money with them:

Weißt du was: wir nehmen einen Strick

Binden Celestina an den Schemel

Und den Schemel rücken wir ans Feuer.

Inquisition. Und schleunigst teilt die ehrlich.

(Do you know that we will take a rope

And tie Celestina to the stool

And we will move the stool to the fire.

Inquisition. And at once she will share.) (179)

The second scene about the Inquisition is very short. The Inquisitor has Calisto's, Melibea's, Celestina's and her accomplices' files put away into the archive for dead people, although they are still alive at the time. It serves as final proof that the Inquisition indeed planned the deaths of all five protagonists.

To make sure the audience understands that his adaptation of Celestina refers to the context of the GDR, Mickel also plays with the double meaning of words that were typical for the language of party officials, the socalled Parteichinesisch / (party Chinese). An example is the expression «die Sache» / ("cause» or "matter») when Sempronio asks Celestina: «Warst du in der Sache unterwegs?» / (Were you busy for die Sache?») (180). In Helga Königsdorf's novel Im Schatten des Regenbogens, for instance, the protagonist Alice recalls her joining the party with the following words:

Als ihr der Alte damals die Hand gedrückt hatte, erlebte sie einen Moment tiefer religiöser Hingabe. Sie spürte, dass es noch eine höhere Liebe gab als die Liebe zwischen Mann und Frau. Die Liebe zur Sache. Was das auch immer war. / (In those days when the old man shook her hand, she experienced a moment of deep religious devotion. She felt that there was a higher love than the love between a man and a woman, the love of die Sache. Whatever that was) (86, italics added by the author of this article).

For us today it is hard to imagine what political impudence Mickel showed by using a communist holy word «die Sache» in the context of Celestina's intrigues. The situation is the following: To make even more money with the "Sache," Celestina has Pleberio, Melibea's father, informed about Calisto's sexual interest in his daughter. Pleberio pays 
Celestina for this information and has his daughter put in a convent. Afterwards, Calisto -informed by Celestina's accomplices about this change of place- seduces Melibea in the convent's garden. With Sempronio's and Celestina's use of the expression "die Sache» in the context of their criminal intentions, the word becomes a dirty touch that probably reflects Mickel's dislike of this word. After all, Stalin's notorious purges against hundreds of thousands of his own comrades during the 1940s, in party meetings, had been justified by "die Sache».

As Rodiek points out, in order to highlight Calisto's «Erkenntnisprozess» / ("process of discovery») (168) about the deficiencies of the society he lives in, Mickel changes Fernando de Rojas plot in another important way: Calisto, who did not consider a marriage with Melibea because of her mother's Moorish ancestors, finds letters according to which Parmeno, his servant and a murderer, is probably his half brother and he himself not of noble birth. This shocking discovery causes a deep identity crisis in Calisto and later, in Melibea's arms, a process of realization that «den Bewusstseinsstand postfeudaler Gesellschaftsformationen vorwegnimmt» / («anticipates the knowledge of post-feudal societies») (Rodiek 168). Calisto says:

Adel oder Pöbel

Spanier Mohr Indianer, Henker Hexe

Was miteinander Junge machen kann

Alles ist Eins.

Gott würfelt. Gott ist tot. Kein höhres Wesen

Ist, als der Mensch. / Und das sieht so aus.

Ich sehe nackte Affen, Melibea!

(Nobility or rabble

Spaniard Moor Indian, hangman witch

Who can make babies with each other

All are the same.

God is playing at dice. God is dead. No higher being

Exists than man. And it looks like that.

I see naked monkeys, Melibea!) (202-3)

After this heretical statement, Calisto - this is now clear to the audience who saw the members of the Holy Office in front of the curtainmust die. In his interpretation of Calisto's death, Rodiek states correctly: "Die Ausweglosigkeit eines neuen, aber von den soziohistorischen Möglichkeiten isolierten [...] individuellen Bewußtseins — diese Lektion will der Autor seinem Publikum vermitteln». / ("The hopelessness of a new, but from the socio-historic possibilities isolated [...] individual consciousness - this lesson the author wants to teach the audience».) (169).

In Wekwerth's play, written three years after the fall of the Berlin Wall and two years after German reunification, the Inquisition's planning and 
directing of what happens on the stage is missing. Instead of introducing the figures of the Inquisitor and his secretary, the author adds a fat priest to the ensemble of de Rojas' protagonists. The priest comes to Celestina's house to have sex with Elicia, a prostitute - a criticism of the hypocrisy of the Church. As is well known, the GDR was an atheist state. Although religion was not forbidden, its followers were treated unfavorably. German reunification also meant for the East Germans that state and church were united again with the consequence that people who confessed to be Christians had to pay church-rates. Wekwerth's introduction of the figure of the hypocritical priest is meant without doubt as a criticism of the recent institutionalizing of the Church in the East.

However, the major motif for Wekwerth's changes in the story line of Fernando de Rojas' text is the corrupting power of "totale Vermarktung» / ("total marketing») (117) that came along with the introduction of capitalism in East Germany as a consequence of German reunification. With the figure of Celestina as designed by Fernando de Rojas, the author does not have to introduce new figures that represent capitalism into de Rojas ensemble. Ottavio di Camillo put it this way:

es ella [Celestina] la que lleva las cuentas, como un gran mercader florentino, utilizando la recién inventada 'partida doble' en que anota todas las niñas que nacen en la ciudad, y es ella la que va marcando el tiempo al ritmo de las campanadas del reloj y va midiendo las horas, como un newyorkino cualquiera, por la ganancia que puede realizar. (74)

Instead, Wekwerth intensifies all dialogues that concern money and invents new ones. In one instance, Parmeno, one of Calisto's servants, steals his master's sword and tries to sell it to Celestina —an incident that is missing in the Spanish original. Celestina, a master of theft on a bigger scale, refuses to buy the weapon: «Du bringst ihn sofort dem Eigentümer zurück. Diebesgut nehme ich nicht. [...] Bei mir gilt: Du sollst nicht stehlen. Jedenfalls wenn es sich nicht lohnt». / ("You will return this to its rightful owner immediately. I do not take stolen things. [...] I believe in: Thou shall not steal. Or, at least when it is not worth the effort») (45). In the following scenes, Parmeno learns from her how to rob his master of things that are much more valuable than a sword.

To make sure that the audience really understands the relevance of his adaptation of Celestina to what had recently happened in Germany, Wekwerth has Sempronio say in the first act: «seit unser Ferdinand die schöne Isabella von Kastilien geheiratet hat, haben wir die Wiedervereinigung. Spanien ist wieder eins» / ("Since Ferdinand married the beautiful Isabel from Castile, we have the reunification. Spain is one country again») (9) 
-a direct hint at German reunification. Afterwards, Wekwerth goes into detail to describe this new time after having become one country:

Die Ausländer mußten raus, und dafür haben wir uns Granada genommen und diesen Muselmann von Emir zum Teufel gejagt. Seitdem blühen Handel und Wandel. Und die Inquisition. Sie sorgt dafür, daß alle alles glauben und daß man genug Böse findet, um sie dort hinzuschicken, wo sie hingehören: Auf den Scheiterhaufen. Ja, wir leben in Gottes eigenem Land und alle reden von Aufschwung. / (The foreigners had to leave and for this reason we have taken over Granada and we have sent the Muslim from Emir to hell. Since then, life and commerce are flourishing. And the Inquisition. It makes sure that everyone believes everything and that enough evil ones are located to be sent where they belong: the stake. Indeed, we live in God's chosen land and everyone talks about progress.) (9)

This statement insinuates 1) that the rigid German policies against foreigners were the result of the fall of the Berlin Wall and 2) that the omnipresence of the secret police in East Germany was nothing but a result of the fall of the Wall and of German reunification. Both insinuations misrepresent historical facts:

1) Although it is true that foreigners, mainly Vietnamese, had to leave East Germany in 1992, the rigid policy against foreign asylum seekers who could not prove that they were persecuted in their home countries was German policy before this time. In addition, the GDR had welcomed the Vietnamese and people from other countries because its inefficient economy continuously suffered from a lack of workers. With German reunification and the shutdown or restoration of East German factories, this situation changed over night.

2) To highlight the omnipresence of the state police after German unification and to pretend that it did not exist before is ridiculous in light of the scandals that the opening of the GDR Stasi files caused right at the time when Wekwerth wrote this play. However, it is also possible that the mentioning of the Inquisition in Wekwerth's adaptation of Celestina refers to the West Germans who investigated Stasi archives to find evil East Germans and to condemn them. Given both interpretations, Wekwerth's adaptation of Celestina clearly criticizes Mickel's work so far as his representation of the Holy Office of the Inquisition is embedded in the context of the GDR and aims to criticize this totalitarian version of socialism. It must be mentioned that Wekwerth was the former president of the GDR's academy of arts - a position he had been given by the party. After German reunification, he lost this influential job. His text, 
without doubt, is influenced by his bitterness about this loss and a proof that critics have been right to ask: "Frente al 'esencialismo'de '¿Qué es la Celestina?', la razón hermenéutica enfrenta una cuestión mucho más exigente y reveladora: '¿Qué ha sido y es, para nosotros, la Celestina?’» / "Faced with the 'essentialism' of [the question] 'What is Celestina?,' the hermeneutic reason confronts a much more demanding and informative question: 'What was and what is, for us, Celestina?'” (quoted from a student's MA thesis in Snow 278). The fact is that for Karl Mickel in 1974 and for Manfred Wekwerth in 1992, Fernando de Rojas' Celestina: Tragicomedia de Calisto y Melibea seems to consist of two completely different texts.

Nevertheless, both adaptations are convincing interpretations of Celestina. Reading Stephen Gilman's analysis of the sociopolitical context in which Fernando de Rojas wrote Celestina, the similarity of both contexts, at that time and today, is amazing. As during Fernando de Rojas' life in Spain at the end of the fifteenth century, when a radical change from the medieval to the early modern society took place, people today in East Germany experience the transition from a strictly stratified, semi-feudal society to a capitalist one with the brutal reign of the rules of the market. For readers unfamiliar with life in the former GDR, see Rudolf Bahro's famous analysis The Alternative in Eastern Europe (1980). Bahro's reasons for drawing a parallel between actually existing socialism in the GDR before the fall of the Iron Curtain and feudal societies are the following: «its bureaucratic-centralist organization of labor, its character as a stratified society, the marked impotence of the immediate producers, its relatively weak impulse towards raising productivity, its political-ideological organization as a quasi theocratic state» (13). Since the context of fast emerging capitalism is reflected in Fernando de Rojas' text (see, for instance, Celestina's obsession with increasing her income), Manfred Wekwerth's interpretation that focuses on the word "money» is not at all too far-fetched. However, neither is Karl Mickel's if we consider that his adaptation was written twenty-eight years before Wekwerth's, meaning before the collapse of the GDR. In my opinion, Fernando de Rojas' situation as converso during the time of the Inquisition is not without similarities with Mickel's situation as a critical intellectual behind the Iron Curtain where the party trials and the surveillance by the state police gave an Inquisitional quality to life. Given this similarity, Gilman's description of a critical mind at the end of the fifteenth century - "forced back on itself, unsure of its beliefs, pursued by the suspicion of countless watchers and spies, resentful, fearful» (178)— could fit for both Fernando de Rojas and Karl Mickel. Although we know little about the Spanish author's feelings towards the Inquisition, Gilman showed that his father-in-law had been accused of secretly being a Jew - a fact that certainly influenced de Rojas' perception of reality. Mickel, on the other hand, was attacked severely 
by functionaries of the party for his poem "Der See» / "The Lake» in 1963. Hans Koch, for instance, director of the GDR's writers' organization, denounced the poem to be sick due to its ambiguity. The lines «See, schartige Schüssel, gefüllt mit Fischleibern / Du Anti-Himmel» / ("Lake, chipped bowl, filled with bodies of fish / You Anti-Heaven») (Mickel 145), according to Koch, were incorrect from a social and historical point of view. As Ijoma Mangold showed in her interpretation of Mickel's poem:

Die amtliche Geschichtsphilosophie und eschatologische Fortschrittserzählung von der Befreiung des Subjekts verwandelte sich da zu einem unterirdisch-organischen Danse macabre, zu einer negativen Naturgeschichte, in der sich einzig Leid, Wunden und Schmerz [...] fortpflanzen.

(The official philosophy of history and eschatological narration of historic progress of the liberation of the subject was changed to a underground-organic Danse macabre, to a negative natural history, in which only suffering, wounds and pain are being reproduced.) (2)

After this attack «in der die orthodoxen Kritiker ihre Ignoranz und Engstirnigkeit unverhüllt zur Schau stellten» / («in which the orthodox critics showed openly their ignorance and narrow-mindedness») (Emmerich 233) and other acts of ideological disapproval (one had to do with an anthology of poetry In diesem besseren Land that Mickel and his friend, Adolf Endler, published in 1966), Mickel did not become a dissident writer who would publish critical books about life in the GDR illegally in the West, constantly running the risk of being arrested. Instead, he withdrew from public debates about literature into a close circle of equally critical-thinking friends that he called «Sächsische Dichterschule» / («Saxon School of Poets») - a kind of collective inner emigration.

Returning to Wekwerth's play, in addition to being an interesting representation of the bad feelings of a member of the GDR's elite about the fall of the Wall, his adaptation of Celestina is important for another reason. During the 1960s, the author had worked with Bertolt Brecht at the Berliner Ensemble; his adaptation of Celestina shows his master's influence in several instances. The following example reminds us of Brecht's Three-Penny Opera written and staged in 1928 when Brecht was beginning to explore Marxism. In this famous work, Brecht satirizes the bourgeois society of the Weimar Republic by praising the intelligence of the small criminals in their struggle for survival in a society that is ruled by the big criminals. Wekwerth's protagonist Celestina seems to be taken directly from Brecht's world of beggars, thieves, and prostitutes and is evidence that Joseph Thomas Snow's suspicion «that a collective secret admiration for [Celestina's] ability to outfox, outwit and out-maneuver, 
almost at her will, her social superiors has been an important ingredient of her longevity» $(2000,9)$. Like Jonathan Peachum, Brecht's king of beggars, she acts as an entrepreneur and "has the instincts of a contemporary market researcher» (Lazere 1 ). In act six, for instance, her accomplice Sempronio urges her to help Calisto to see Melibea immediately. After all, he paid for it more than generously. Celestina who wants even more money rejects this proposal with the following words: "Man zahlt nur für das, was man nicht hat. Und je länger es fehlt, desto größer der an sich unnatürliche Drang, Geld herzugeben». / "We only pay for what we do not have. And the longer we are lacking this the more we have the unnatural desire to pay money for it») (41). This is too much for Sempronio: "Ich finde, du gehst zu weit. Ich bin zwar nur ein kleiner Dieb, aber ich achte die Menschen, die ich bestehle». / («I think, you go too far. I am, to be sure, only a small thief, but do respect the people who I steal from») (41). Celestina answers: "Ich eben nicht, ich kenne sie. Ich gehe davon aus, daß es alles Gauner sind. So können sie mich nie enttäuschen». / "I do not because I know them. I assume that they are all crooks. This way, they cannot disappoint me») (41). After Sempronio's reply: "Dann will ich dir etwas sagen. Auch ich bin ein Gauner, aber ich bin ehrlich. Das bin ich». / («Then I will tell you something. I am a crook, too. But I am honest. This I am») (41), Celestina explains in a typical Brechtian manner her philosophy of life:

Ehrlich sind wir alle. Gaunerei ist die ehrlichste Art, sich der großen Gauner zu erwehren. Wenn du von den Wölfen nicht gefressen werden willst, musst du mit ihnen heulen, wie sollen sie sonst Vertrauen zu Dir haben. [...] Willst du nicht, dass man dir die Ohren abschneidet, musst du den andern übers $\mathrm{Ohr}$ hauen, das erwartet der sogar von dir. So schließt sich der Kreis der Gerechtigkeit und das schöne Sprichwort bewahrheitet sich: Ehrlich währt am längsten. / (We all are honest. Swindling is the most honest way to protect one against the big rogues. If you do not want to be killed by the wolves, you will have to join them howling. Otherwise, how should you gain their confidence? [...] If you do not want them to cut your ears off, you will have to cheat the other; in fact, you are expected to do just that. This is how the circle of fairness is completed: Honesty lasts the longest.) (41)

The fact that Celestina has to die anyway - as in the Spanish original, she is murdered by her own accomplices because she doesn't want to share the money received from Calisto- is due not to perfect planning by the Holy Office as in Mickel's adaptation, but rather it happens as a 
result of the decline of morals in the market society. Wekwerth explains this in his notes following the text of the play:

Und da [Celestina] nicht aufhört, ihnen [ihren Freunden] lang und breit zu beweisen, daß große Zeiten auch groß sind, weil sich alles, Freundschaft eingeschlossen, zu Markte tragen läßt, fragen sie sich irgendwann, warum sie ihre Freundschaft zu Celestina nicht zu Markte tragen sollen. / (And because Celestina doesn't stop to prove to them [her friends] at great length that great times are also great because you can sell everything, friendship included, they ask themselves some time why they shouldn't sell their friendship with Celestina.) (Wekwerth 115)

In addition, Wekwerth uses elements of Brecht's epic theatre to destroy the audience's identification with the protagonists and to cause alienation. At the end, for instance, Pleberio, Melibea's father, addresses the audience with the following words:

An dieser Stelle, verehrtes Publikum, müssen wir die Tragikomödie um Calisto und Melibea abbrechen. Die Nachricht von den schrecklichen Ereignissen sprach sich noch in derselben Nacht herum, so daß die halbe Stadt zusammenlief. Das können wir mit unseren bescheidenen Mitteln nicht darstellen. Auch müssen wir Sie um Nachsicht bitten, daß wir die Trauer nicht unbegrenzt ausdehnen können, da wir alle Kräfte zum Abbau der Dekoration brauchen. Wir sind ein kleines Theater. Und wenn die Toten nun wiederaufsterstehen müssen, behalten Sie sie und uns alle dennoch in guter Erinnerung. / (At this point, Ladies and Gentlemen, we have to stop the tragicomedy of Calisto and Melibea. The news about the horrible events got around during the same night so that the whole city gathered. This we cannot show with our modest means. Also, we have to ask for your leniency that we can't extend the mourning indefinitely because we need everybody to take down the decoration. We are a small theatre. And when the dead must rise up, keep them and all of us in good memory.) (113)

As Brecht explained in his notes about Aristotle's concept of catharsis, the uncritical identification of the audience with the protagonist's destiny is dangerous because the public might be seduced by this identification. Instead, the audience should be enabled to use its own judgment to think critically about the protagonist. To reach this goal, Brecht introduces cer- 
tain epic elements that interrupt the identification and enable the audience to discover connections and contradictions that go beyond the subjective awareness of the protagonists. One such element is addressing the audience directly. Both in Fernando de Rojas' and in Manfred Wekwerth's text, Pleberio, Melibea's father, has the last word. However, while in Fernando de Rojas' text Pleberio ends the play lamenting bitterly about the world, this «río de lágrimas, mar de miserias» (264), and has the audience identify with his pessimism, Wekwerth's figure of Pleberio, addressing the audience about logistics of the performance of the play, creates distance between the actor and his role. This way, the audience is able to obey Brecht's rule: «Ich lache über den Weinenden, ich weine über den Lachenden» / ("I laugh about the one who cries, I cry about the one who laughs») (Brecht, Schriften 254). Pleberio's Baroque grief, according to Wekwerth, should be laughed away. In this way, he prevents the audience from leaving the theatre with a pessimistic worldview that would be incompatible with Brecht's optimism based on the conviction that the prevailing order can be overthrown and the world changed. Christel Berger stated about the theater production of Wekwerth's Celestina in Wuppertal in 2002: "Brecht hätte seine Freude [daran] gehabt» / "Brecht would have derived pleasure from it») (4). He would have derived even more pleasure in view of the fact that in Wekwerth's text, Celestina teaches Parmeno a lesson about masters and servants that is a reference to Brecht's «model analysis of the master-servant relationship» (Mews, 31) in Herr Puntila und sein Knecht Matti (1948). Parmeno reproaches her: "Mit deinen Versprechungen blendest du ihm die Augen für jegliche Vernunft» / («With your promises, you blind his eyes for any reason») (34). Celestina, replies:

Vernunft! Was ist Vernunft? Meinst du, Kindskopf, was für deinen Herrn Vernunft ist, ist es auch für dich? Für deinen Herrn ist es vernünftig, dich zu schinden, dafür ist er ein Herr. Und nennt er dich seinen Freund, tut er das nicht aus Freundschaft, sondern um dich noch mehr zu schinden, weil du für ihn kein Wesen mit Haut und Haaren bist, sondern ein Gegenstand, den er besitzt, sagen wir ein Stiefelknecht. Ein Stiefelknecht wird nicht nach seiner Moral gefragt, sondern danach, ob er Stiefel auszieht. / (Reason! What is reason? Do you think, fool, what is reason for your master it is also for you? For your master, it is reasonable to maltreat you, for that he is a master. And when he calls you his friend, he doesn't do this for friendship, but to maltreat you even more, because you are not a human being for him, but an object 
that he owns, let's say a bootjack. You don't ask a bootjack for his morals, but if it takes off boots.) (34)

Brecht in Herr Puntila und sein Knecht Matti explores the relationship between master (a rich landowner) and servant (his chauffeur) with the result that the servant turns his back on the master, stating: «s' wird Zeit, daß deine Knechte dir den Rücken kehren. / Den guten Herrn, den finden sie geschwind / Wenn sie erst ihre eignen Herren sind». / "It's at the time that your servants leave you. / The good master they will find quickly / Once they have become their own masters») (Brecht, Stücke II 334). It is Brecht's answer to the problem of the difficult relationship between master and servant that according to Wekwerth today - «im Umkreis des gefräßigen Neoliberalismus» / "in the context of the voracious neoliberalism» (2000,375- has a new relevance. In an interesting article titled «Teatro de Brecht. ¿Una respuesta a nuestra tiempo?» Wekwerth argues that Brecht's Marxist theater is not at all outdated after the collapse of the socialist experiment in Eastern Europe:

El triunfo del capitalismo es al mismo tiempo su gran pérdida: el capitalismo ha perdido la imagen del enemigo, la cual no se puede sustituir con Bin Laden ni con ningún estado bribón. Es el «reino del mal» lo que Ronald Reagan entendía por comunismo, pues la imagen enemiga del «fantasma del comunismo» era lo que mantenía más o menos unidos a los hostiles hermanos capitalistas, y frenaba el desmontaje de lo humano y lo social, ahora practicado sin obstáculos. Ya que sin la fuerza opuesta [...] el capitalismo se vuelve despiadado y sin límites, y regresa a su normalidad, es decir, a Marx. (3)

A sign of this development for Manfred Wekwerth has been the massive unemployment in East Germany during recent years - a phenomenon that Brecht dealt with in Die heilige Johanna der Schlachthöfe in 1930.

To summarize, in this study I compared two East German adaptations of Fernando de Rojas' famous text Celestina: Tragicomedia de Calisto y Melibea - written before and after the fall of the Wall and German reunification. Both adaptations change Fernando de Rojas' story line in very different ways. While Mickel, reveling in the subversive aspects of the work, introduces two members of the Inquisition into the ensemble of the protagonists who, invisibly for the protagonists but not for the audience, plan and direct the plot, Wekwerth introduces the figure of a fat priest who indulges in sex with one of the prostitutes. In addition, Wekwerth intensifies Celestina's greed and entrepreneurial abilities by adding more dialogues between her and her accomplices that circle around the word "money». The reasons for these different changes are sociopoliti- 
cal. While Mickel uses Fernando de Rojas' text to have a critical look at East German reality before the fall of the Wall with its omnipresent state police, Wekwerth uses the same text to articulate his unhappiness about the introduction of market economy in this part of the world. Having been a student of Brecht, the author uses his adaptation of Celestina to show that Bertolt Brecht's view of the world and its theatre is still relevant after the collapse of the socialist experiment in Eastern Europe.

\section{Bibliographie}

Bahner, Werner. «La Celestina en el teatro de la República Democrática Alemana». Manuel Criado de Val (Ed.) La Celestina y su contorno social: Actas del I Congreso Internacional sobre La Celestina. Barcelona: Borrás, 1977: 485-9.

BAHRO, Rudolf. The Alternative in Eastern Europe. Oxford: NLB, 1978.

Berger, Christel. "Unverwüstliche Celestina». [Online.] >http://www. jungewelt.de/2002/10-29/018.php $<8 / 5 / 2005$.

Brecht, Bertolt. "Herr Puntila und sein Knecht Matti». Stücke II. Berlin: Aufbau, 1973.

— «Das epische Theater». Schriften. Berlin: Aufbau, 1973.

Briesemeister, Dietrich. "Die Sonderstellung der 'Celestina'». Das Spanische Theater: Von den Anfängen bis zum Ausgang des 19. Jahrhundert. (Ed. Klaus Pörtl). Darmstadt: Wissenschafliche Buchgesellschaft, 1985: 91 108.

Costa Fontes, Manuel da. The Art of Subversion in Inquisitorial Spain. West Lafayette: Perdue U P, 2004.

Di Camillo, Ottavio. «Ética Humanística y Libertinaje». Humanismo y literature en tiempos de Juan de Encina. Salamanca: Ediciones Universidad de Salamanca, 1999, 69-82.

ECKART, Gabriele. "Unstreitig ist mein armer Herr ein Ketzer». Glossen. 20 (2004). [Online.] <http://www.dickinson.edu/departments/germn/ glossen/heft20/celestina.html> 11/29/2004.

EMmerICH, Wolfgang. Kleine Literaturgeschichte der DDR. Leipzig: Kiepenheuer, 1997.

ENDLER, Adolf, Mickel, Karl. In diesem besseren Land: Gedichte der Deutschen Demokratischen Republik seit 1945. Halle: Mitteldeutscher Verlag, 1966.

Gilman, Stephen. The Spain of Fernando de Rojas: The Intellectual and Social Landscape of La Celestina. Princeton: Princeton UP, 1972.

KönigsDorf, Helga. Im Schatten des Regenbogens. Berlin: Aufbau, 1993. 
Lazere, Arthur. «The Threepenny Opera». [Online.] <http:www.culturevulture.net/Theater/Threepenny.htm> 8/5/2005.

MANGOLD, Ijoma. "Stehlt soviel ihr nur könnt: Zum Tod des Lyrikers, Eassayisten und Dramatikers Karl Mickel». Online. <http://www.berlinonline.de/wissen/Berliner-zeitung/.bin/dump.fcgi/2000/0622/feuilleton/0013/> 2/22/03.

MEws, Siegfried. «A Merry Departure from the Past? Master-Servant Relations in Bertolt Brecht, Martin Walser, and Volker Braun». Frank Pilipp (Ed.). New Critical Perspectives on Martin Walser. Columbia: Camden House, 1994: 29-46.

Mickel, Karl. "Celestina oder Die Tragikomödie von Calisto und Melibea». Schriften 3: Halsgericht. Leipzig: Mitteldeutscher Verlag, 1993.

-.Vita nova mea: Mein neues Leben. Berlin: Aufbau, 1966.

RODIECK, Christoph. "Das Inquisitionsmotiv in neueren deutschsprachigen Bühnenfassungen der Celestina». Arcadia. 25, 2 (1990): 160-71.

RojAs, Fernando de. Celestina: Tragicomedia de Calisto y Melibea. Miguel Marciales (ed.). Urbana: U of Illinois P, 1985.

Snow, Joseph Thomas. "Five Centuries of 'Celestina' Readings: An Overview and an Example from the Nineteenth Century». Fernando de Rojas and Celestina: Approaching the Fifth Centenary". Ivy A. Corfis and Joseph T. Snow (eds.). Madison: Hispanic Seminar of Medieval Studies, 1993: 267-81.

-. "Celestina (1499-1999) Medieval and Modern: Survival \& Renewal of a Spanish Classic». Medieval perspectives 15 (2000): 1-11.

WeKWERTH, Manfred. Erinnern ist Leben: Eine dramatische Autobiographie. Leipzig: Faber \& Faber, 2000.

-. Fernando de Rojas. Celestina. München: Drei Masken, 2002.

-. «Teatro de Brecht. ¿Una respuesta a nuestra tiempo?» [Online.] $<$ http://www.casadelasamericas.com/revistaconjunto/132/manfred. htm> 8/5/2005.

ZINGG, Martin. «Wirtschaftshistoriker und Dichter: Zum Tod des Schriftstellers Karl Mickel». Neue Zürcher Zeitung. 06/23/2000. 


\title{
ECKART, Gabriele, "Celestina - a Spanish Novel on the East German Stage before and after German Reunification", Celestinesca 30 (2006), pp. 27-41.
}

\begin{abstract}
This study compares two East German adaptations of Celestina -written before and after German Reunification in 1990. Both adaptations change Fernando de Rojas' story line in very different ways. While Karl Mickel introduces two members of the Inquisition into the ensemble of the protagonists who plan and direct the plot, Manfred Wekwerth introduces the figure of a hypocrite priest and also intensifies Celestina's greed and entrepreneurial abilities by adding more dialogues between her and her accomplices that circle around the word "money". The reasons for these different changes are sociopolitical. While Mickel uses Fernando de Rojas' text to have a critical look at East German reality before the fall of the Wall with its omnipresent state police, Wekwerth uses the same text to express his unhappiness about the introduction of market economy in this part of the world.
\end{abstract}

KEY WORDS: Cetestina, translation, theatre, Germany.

\section{RESUMEN}

Este estudio compara dos adaptaciones alemanas de Celestina - una escrita antes y otra después de la reunificación de Alemania en 1990. Las dos adaptaciones cambian el argumento de Fernando de Rojas de diferente forma. Mientras Karl Mickel introduce dos miembros de la Inquisición, los cuales planifican y dirigen la trama, Manfred Wekwerth introduce un cura hipócrita y, por otra parte, intensifica la codicia y las habilidades comerciales de Celestina, para lo cual añade diálogos entre ella y sus cómplices referentes al "dinero». En los dos casos, las razones de los diferentes cambios son socio-políticas. Mientras Mickel usa el texto de Fernando de Rojas para criticar la realidad de Alemania oriental antes de la caida del Muro con su policía secreta omnipresente, Wekwerth usa el mismo texto para expresar su descontento sobre la introducción del capitalismo en esta parte del mundo.

PALABRAS ClAVE: Celestina, traducción, teatro, Alemania. 


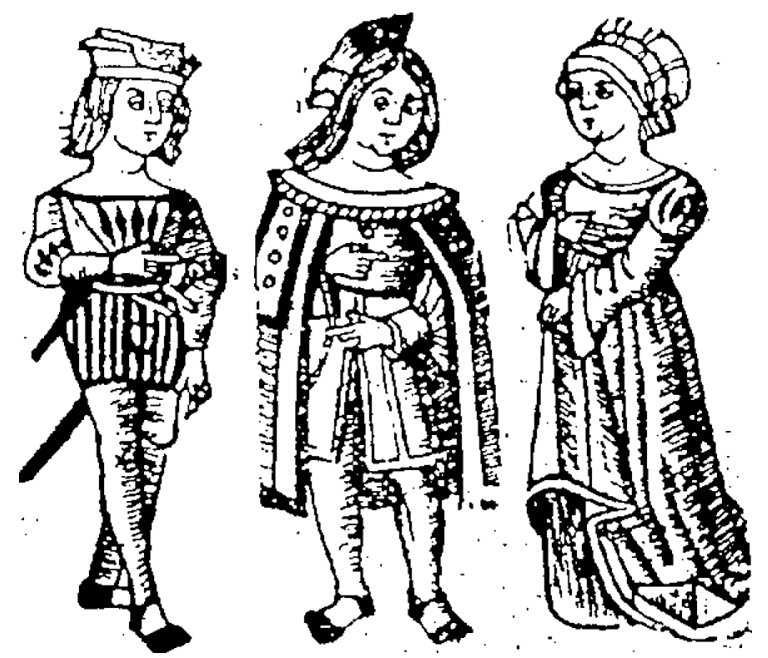

